\title{
PENGARUH CAMPURAN AIR LAUT TERHADAP KUAT TEKAN BETON AGREGAT RECYCLE
}

\author{
Lusman Sulaiman ${ }^{* 1}$, Amiruddin Akbar Fisu \\ 1Dosen / Jurusan Teknik Sipil / Universitas Andi Djemma \\ 2 Dosen / Jurusan Teknik Sipil / Universitas Andi Djemma \\ Korespondensi: sulaimanlusman@gmail.com
}

\begin{abstract}
High consumption of freshwater and natural aggregate in concrete production becomes a matter of some concern that has been discussed recent years. An alternative partially or totally replacement for both materials is significant issue to reduce the negative impacts on the environment. Therefore, the aim of this research is to observe explicitly the effect of using seawater as mixing combined with recycled coarse aggregate and other material to make new recycled aggregate concrete (RAC) under compressive load. The experimental laboratory test was conducted to total of thirty cylinders specimens of two to groups of mix design with $w / c$ of 0.45. First was three types of percentage level of recycled coarse aggregate with targeted compressive strength of $25 \mathrm{MPa}$. The second was two types of mixtures and totally replaced by recycled coarse aggregate with targeted compressive strength of $30 \mathrm{MPa}$. Some specimens were mixed by seawater and all were placed in the freshwater-curing during some definite period of 7 and 28 days. The results show that the seawater and recycle aggregate were not significant influence to reduce the compression strength for first mix category, while the second mix category was having great influence up to $22 \%$ at 28 days. The reduction in compressive strength increases with an increase the targeted compressive load.
\end{abstract}

Kata Kunci : Compressive strength, recycled coarse aggregate, recycled concrete, seawater

\section{PENDAHULUAN}

Beton agregat recycle (BAR) telah banyak diteliti dan dikembangkan oleh para ahli karena memiliki sifat-sifat yang hampir serupa beton agregat normal (BAN) baik ditinjau dari sisi durabilitas maupun kekuatan [1] [2]. Beton BAR yang tersusun dari material recycle agregat kasar (RAK) dengan karakteristik utama seperti kepadatan, porositas dan penyerapan, bentuk dan gradasi, dan abrasi cukup berbeda dengan natural agregat kasar (NAK), akan tetapi posibilitas untuk membuat beton struktural sangat dimungkinkan untuk dilakukan [3]. Selain itu, perkembangan konstruksi beton yang massive dan lebih banyak mengerah ke pantai atau laut merupakan tantangan dalam penyediaan material penyususn beton, Sehingga ketersediaan material campuran beton seperti NAK dan air tawar semakin sulit untuk dijangkau dari sumber-sumber alamiahnya.
Sehingga pemanfaatan material RAK dan Air laut yang jumlahnya menempati $70 \%$ permukaan bumi menjadi alternative pengganti dalam campuran beton. Ditambah jika sumber air tawar dan NAK tidak ada atau terlampau mahal [4]. Namun, kajian mendalam sangat perlu untuk dilakukan untuk kedua material campuran tersebut. Sejauh ini, penelitian tentang pemanfaatan air laut sebagai campuran dalam pembuatan beton BAR masih sangat jarang dilakukan. Dengan melihat potensi begitu besar terhadap kedua material dalam menghasilkan beton yang memiliki bahan dasar ramah terhadap lingkungan, maka penelitian ini dilakukan. Sehingga tujuan penelitian ini adalah untuk mengetahui pengaruh air laut sebagai material pencampuran dalam pembuatan beton BAR pada saat setelah diberikan beban tekan. 


\section{TINJAUAN PUSTAKA}

Durabilitas beton adalah hal yang paling penting dalam penentuan ketahanan terhadap berbagai kondisi lingkungan seperti lingkungan air laut. Kerusakan beton akibat kondisi lingkungan air laut yang agresif menjadi topik menarik untuk dikaji lebih mendalam. Beberapa peneliti telah melakukan studi dengan menggunakan air laut bukan hanya sebagai campuran dalam pembuatan beton tetapi juga sebagai air perawatan [5] [6] [7]. Oleh karena itu, hal ini menjadi objek dinamis untuk dikaji lebih mendalam sebab air laut yang mengandung konstituen utama seperti ion-ion klorida, magnesium, sodium, kalsium dan potasium dimana reaksi kimia air laut pada beton akan dapat membentuk kristalisasi hingga membentuk cairan magnesium hidroxida $(\mathrm{Mg}(\mathrm{OH}) 2)$ dan akhirnya memaksa terbentuknya gypsum yang menyebabkan terjadinya erosi beton [8].

Penelitian terbaru yang menggunakan air laut sebagai material campuran dan air tawar sebagai perendaman dalam memperoduksi beton normal memperlihatkan bahwa terjadi peningkatan kuat tekan dari umur 7 hingga 90 hari dan memiliki nilai berat maksimum di umur 28 hari [4]. Selain itu, menurut studi oleh Akshat Dimri et al. [9] dan Lollini et al. [10] bahwa penggunaan air laut sebagai campuran beton normal nampak tidak mereduksi kekuatan seperti kuat tekan, modulus elastisitas dan lainnya. Akan tetapi, yang perlu diperhatikan pada struktur beton yang terekspose pada kondisi lingkungan air laut baik yang terkena langsung atau tidak adalah korosi tulangan yang dapat dihindari dengan mengaplikasikan besi stainless atau inhibitor.

\section{METODOLOGI PENELITIAN}

\subsection{Material}

Beberapa jenis material digunakan sebagai campuran dalam pembuatan beton yang terdiri dari semen tipe I, pasir sungai, natural agregat kasar, recycle agregat kasar, air laut dan air tawar. Ordinary portland cement (OPC) digunakan dalam campuran pembuatan beton yang komposisinya serupa dengan semen tipe I-ASTM.

Pasir sungai sebagai agregat halus yang memiliki gradasi $0-4 \mathrm{~mm}$ dan natural agregat dan recycle agregat yang memiliki gradasi partikel sebesar 4-20 mm, disiapkan. Agregat recycle diperoleh dengan menghancurkan sisa-sisa sampel beton hasil pengujian kuat tekan di laboratorium dari berbagai proyek local dengan nilai kuat tekan rata-rata 25 30 $\mathrm{MPa}$. Kemudian dilakukan pemisahan antara mortar dan agregat kasarnya hingga penyaringan dan penyortiran untuk mendapatkan ukuran yang diinginkan. Hasil analisis karakteristik agregat seperti terlihat pada Tabel 1.

Gambar 1 memperlihatkan hasil gabungan analisis saringan antara pasir dan kombinasi tiga jenis subtitusi agregat kasar. Terlihat bahwa ketiga jenis kombinasi agregat tersebut masih berada diantara batas atas dan bawah. Hal ini menunjukkan bahwa distribusi ukuran partikel layak digunakan dalam pencampuran produksi beton tanpa perlu dilakukan perlakuan khusus. Ukuran partikel juga cukup berpengaruh terhadap hasil kekuatan pada beton ketika diberikan beban tekan [11].

Tabel 1. Analisis karakteristik fisik dan mekanik agregat kasar dan halus

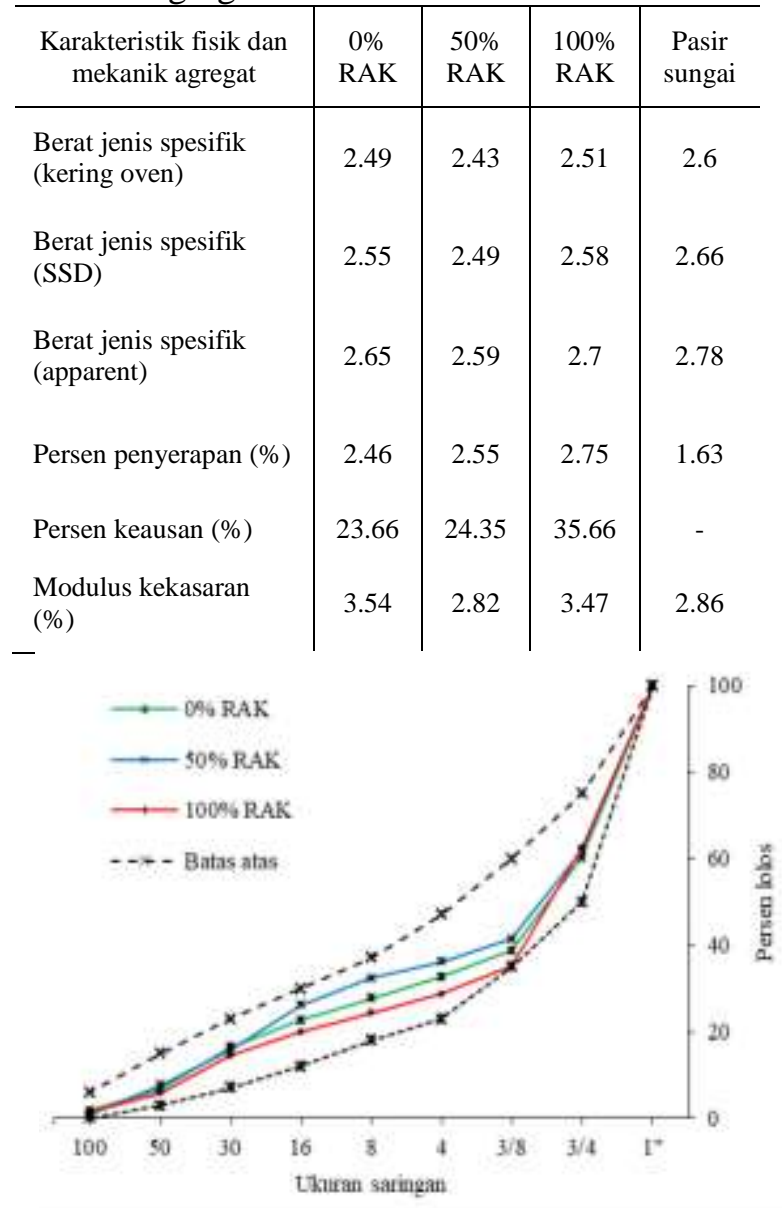

Gambar 1. Analisis penggabungan agregat kasar dan halus 
Tabel 2. Deatail pengujian eksperiman di laboratorium

\begin{tabular}{|c|c|c|c|c|c|c|c|}
\hline Tipe & Kategori & $\begin{array}{l}\text { Material } \\
\text { penyusun }\end{array}$ & $\begin{array}{c}\text { Kuat tekan } \\
\text { rencana (Mpa) }\end{array}$ & Rasio w/c & $\begin{array}{l}\text { Sampel } \\
\text { (buah) }\end{array}$ & $\begin{array}{c}\text { Waktu } \\
\text { perendaman (hari) }\end{array}$ & $\begin{array}{c}\text { Media } \\
\text { perawatan }\end{array}$ \\
\hline \multirow{12}{*}{ 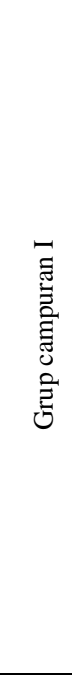 } & \multirow{4}{*}{ B-0 } & Semen type I & \multirow{4}{*}{25} & \multirow{4}{*}{0.45} & \multirow{2}{*}{3} & \multirow{2}{*}{7} & \multirow{4}{*}{ Air tawar } \\
\hline & & Pasir sungai & & & & & \\
\hline & & $\begin{array}{c}0 \% \text { RAK }(100 \% \\
\text { NAK })\end{array}$ & & & \multirow[t]{2}{*}{3} & \multirow[t]{2}{*}{28} & \\
\hline & & Air tawar & & & & & \\
\hline & \multirow{4}{*}{ B-50 } & Semen type I & \multirow{4}{*}{25} & \multirow{4}{*}{0.45} & \multirow{2}{*}{3} & \multirow{2}{*}{7} & \multirow{4}{*}{ Air tawar } \\
\hline & & Pasir sungai & & & & & \\
\hline & & $50 \%$ RAK & & & \multirow{2}{*}{3} & \multirow{2}{*}{28} & \\
\hline & & Air laut & & & & & \\
\hline & \multirow{4}{*}{ B-100 } & Semen type I & \multirow{4}{*}{25} & \multirow{4}{*}{0.45} & \multirow{2}{*}{3} & \multirow{2}{*}{7} & \multirow{4}{*}{ Air tawar } \\
\hline & & Pasir sungai & & & & & \\
\hline & & $100 \%$ RAK & & & \multirow{2}{*}{3} & \multirow{2}{*}{28} & \\
\hline & & Air laut & & & & & \\
\hline \multirow{8}{*}{ 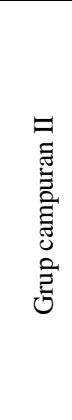 } & \multirow{4}{*}{ BAR-AT } & Semen type I & \multirow{4}{*}{30} & \multirow{4}{*}{0.45} & \multirow{2}{*}{3} & \multirow{2}{*}{7} & \multirow{4}{*}{ Air tawar } \\
\hline & & Pasir sungai & & & & & \\
\hline & & $100 \%$ RAK & & & \multirow{2}{*}{3} & \multirow{2}{*}{28} & \\
\hline & & Air tawar & & & & & \\
\hline & \multirow{4}{*}{ BAR-AL } & Semen type I & & & 3 & 7 & \\
\hline & & Pasir sungai & & & 3 & 1 & \\
\hline & & $100 \%$ RAK & 30 & $0.4 \mathrm{~J}$ & & & AIr tawar \\
\hline & & Air laut & & & 3 & 28 & \\
\hline
\end{tabular}

\subsection{Desain campuran dan pembuatan beton}

Proses desain campuran dalam pembuatan benda uji yang akan diadopsi pada penelitian ini adalah metode BRE/DOE system. Material yang digunakan dalam perencanaan desain campuran pembuatan beton BAR adalah berdasarkan sifat-sifat hasil pengujian yang telah dilakukan dengan benda uji silinder ukuran 150x300 mm, faktor air semen (fas) rencana sebesar 0.45 dan slump beton segar sebesar 80 120 mm.

Dua kategori campuran yang berbeda disiapkan yaitu Pertama adalah dua jenis campuran yaitu air laut $+100 \%$ recycle agregat kasar (BAR-AL) dan air tawar+100\% recycle agregat kasar (BAR-AT) sebagai kontrol beton dengan target kuat tekan $30 \mathrm{MPa}$. Kedua adalah tiga jenis persentase campuran agregat kasar yang berbeda yaitu air tawar $+0 \%$ recycle agregat kasar (B-0) sebagai kontrol beton dengan target kuat tekan $25 \mathrm{MPa}$, air laut $+50 \%$ recycle agregat kasar (B-50), dan air laut $+100 \%$ recycle agregat kasar (B-100). Adapun detail sampel untuk pengujian kuat tekan dapat dilihat pada Tabel 2 .
Tabel 3 memperlihatkan proporsi campuran untuk setiap $1 \mathrm{~m}^{3}$. Proporsi campuran desain pembuatan beton yang telah terbentuk dan dicampur satu dengan lainnya sesuai standar SNI 2439:2011 tentang tata cara pembuatan dan perawatan benda uji beton di laboratorium, yang selanjutnya menghasilkan beton segar dan siap untuk dicetak pada mold silinder.

\subsection{Perawatan dan pengujian}

Tabel 3. Proporsi campuran beton

\begin{tabular}{c|c|c|c|c}
\hline Kategori & $\begin{array}{c}\text { Semen } \\
\left(\mathrm{kg} / \mathrm{m}^{3}\right)\end{array}$ & $\begin{array}{c}\text { Pasir } \\
\left(\mathrm{kg} / \mathrm{m}^{3}\right)\end{array}$ & $\begin{array}{c}\text { Agregat } \\
\text { Kasar } \\
\left(\mathrm{kg} / \mathrm{m}^{3}\right)\end{array}$ & $\begin{array}{c}\text { Air } \\
\left(\mathrm{kg} / \mathrm{m}^{3}\right. \\
)\end{array}$ \\
\hline B-0 & 411.11 & 588.32 & 1122.25 & 185 \\
B-50 & 411.11 & 639.43 & 1537.71 & 185 \\
B-100 & 411.11 & 517.03 & 1585.57 & 185 \\
BAR-AT/ & 411.11 & 681.11 & 1022.77 & 185 \\
BAR-AL & & & & \\
\hline
\end{tabular}

Total 30 sampel dihasilkan dan kemudian dilakukan tahap perawatan umur 7 dan 28 hari dengan menggunakan air tawar. Ketika perendaman telah mencapai periode 
pengujian, sampel kemudian diangkat dan dianginkan untuk menghilangkan air serapan pada beton dalam beberapa saat \pm 24 jam. Hal ini bertujuan untuk memastikan bahwa pada saat pengujian beban tekan maka material tidak terpengaruh oleh air yang terperangkap dalam pori-pori beton.

Pengujian kuat tekan (f'c) sampel silinder beton dilakukan dengan menggunakan alat compression test machine. Kapasitas alat yang akan digunakan pada penelitian ini dapat mencapai beban tekan hingga $50 \mathrm{MPa}$ dan kecepatan secara berkesinambungan rata-rata sebesar 0.14 sampai $0.34 \mathrm{MPa} /$ detik. Setiap pengujian, tiga sampel diuji untuk mendapatkan suatu nilai rata-rata. Keseluruhan prosedur pengujian mengacu pada SNI 1947:2011 tentang cara penguji kuat tekan beton dengan benda uji silinder.

\section{HASIL DAN PEMBAHASAN}

4.1. Efek campuran air laut dan persen variasi pengganti RAK pada kuat tekan beton

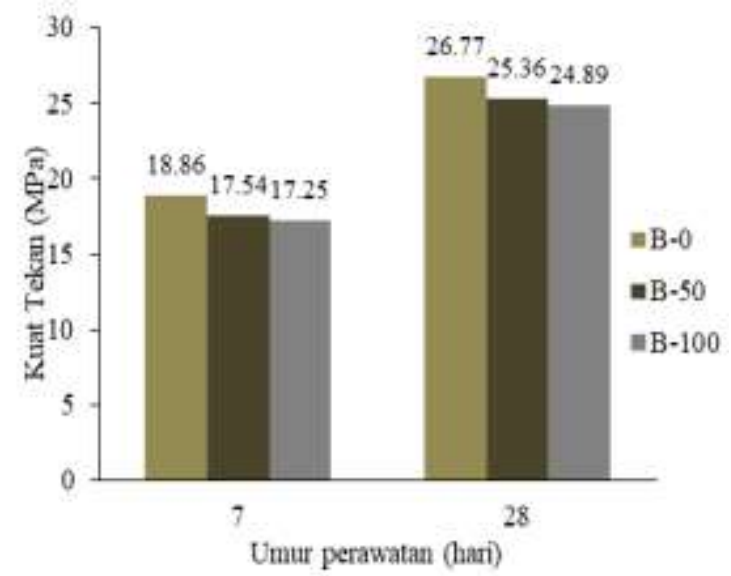

Gambar 3. Hubungan kuat tekan vs waktu perendaman

Hasil pengujian kuat tekan beton dengan persen variasi subtitusi RAK diperlihatkan pada Gambar 2. Hasil pengujian ini adalah rata-rata nilai dari tiga sampel uji untuk pengujian kekuatan 7 dan 28 hari perawatan dengan rencana kuat tekan $25 \mathrm{MPa}$. Terlihat jelas bahwa dengan bertambahnya umur perawatan beton maka akan meningkatkan kuat tekan, akan tetapi dengan bertambahnya persen variasi pengganti RA maka kekuatan tekan beton mengalami penurunan disetiap umur pengujian

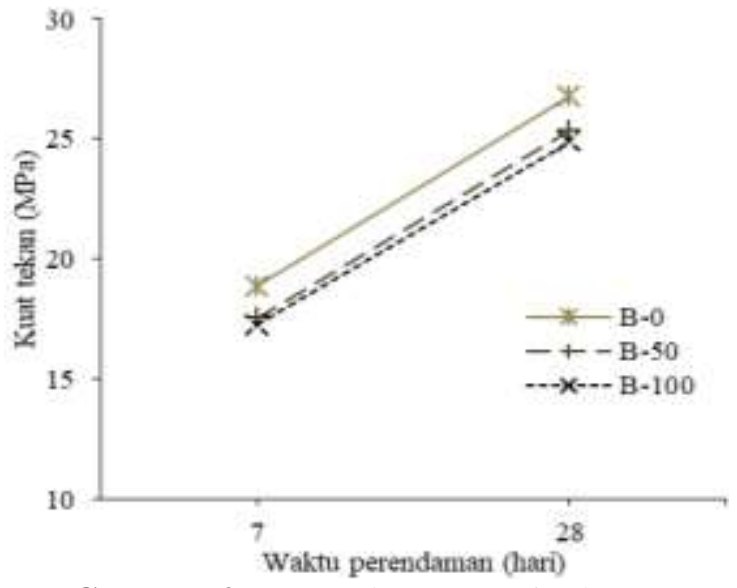

Gambar 2. Kuat tekan vs peningkatan waktu perendaman

sampel. Awal pengujian 7 hari tercatat lebih rendah untuk campuran beton B-50 sebesar 7\% dibandingkan dengan beton $\mathrm{B}-0$ sebagai kontrol beton. Untuk campuran beton B-100 tergambar lebih kecil sebesar $8.5 \%$ daripada beton B-0. Pada umur 28 hari pengujian, kekuatan tekan diperoleh lebih rendah untuk beton B-50 sebesar 5.3\% daripada beton B-0. Sedangkan campuran beton B-100 dibawah sekitar 7.0\% dari beton B-0.

Gambar 3 memperlihatkan kesamaan peningkatan kuat tekan beton untuk pengujian beban tekan dari umur beton 7 hari ke 28 hari. Beton B-0 tercatat mengalami peningkatan signifikan dari $18.86 \mathrm{MPa}$ menjadi $26.77 \mathrm{MPa}$ (29.6\%). Begitu pula halnya dengan beton B-50 dan B-100 terlihat mengalami peningkatan berarti berturut-turut sebesar 17.54 -25.36 MPa (30.9\%) dan 17.25-24.89 MPa (30.7\%).

Dari gambaran ini, pengaruh material recyle agregat cukup rendah terhadap penurunan kuat tekan dengan target sebesar 25 MPa dimana semakin besar persen subtitusi agregat RAK maka semakin semakin besar pengaruhnya terhadap kuat tekan. Hal ini disebabkan oleh karena mortar lama yang masih melekat pada agregat kasar. Sedangkan campuran air laut pada matriks beton B-50 dan B-100 tidak cukup berpengaruh terhadap perilaku kekuatan perilaku tekan beton, yang saat ini diyakini berdasarkan literatur [4].

Begitu pula studi oleh Wegian [8] tentang penggunakan air laut dan air tawar sebagai campuran dan perawatan benda uji. Hasilnya memperlihatkan bahwa air laut digunakan baik sebagai campuran perawatan dalam pembuatan beton akan mengalami 
peningkatan kuat tekan mulai dari umur 7 hingga 28 hari.

\subsection{Efek tanpa dan dengan campuran air laut terhadap kuat tekan beton $100 \%$ RAK}

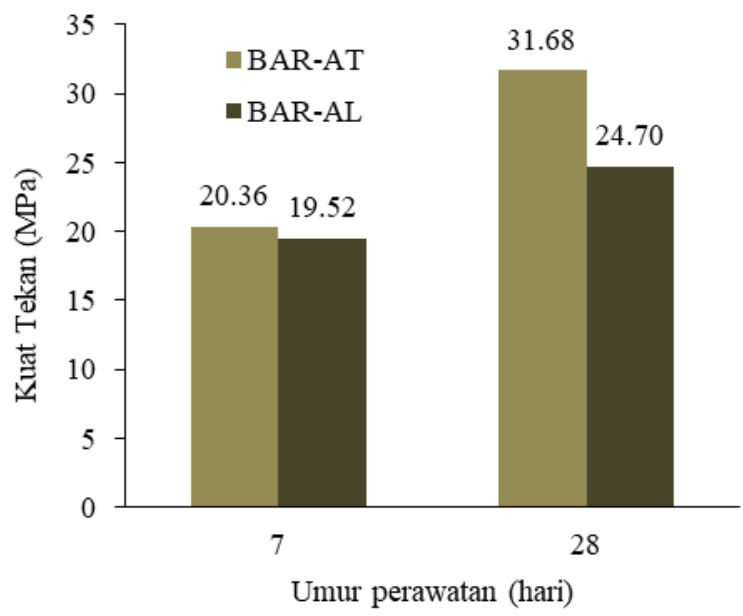

Gambar 4. Kuat tekan vs waktu perawatan

Gambar 4 memperlihatkan hasil pengujian kuat tekan rata-rata sampel silinder pada umur perawatan 7 dan 28 hari dengan target kuat tekan $30 \mathrm{MPa}$. Secara umum terlihat bahwa terjadi peningkatan kuat tekan seiring bertambahnya umur beton $100 \%$ RAK. Namun, setiap umur pengujian beton tergambar mengalami penurunan kuat tekan.

Pada umur 7 hari, kuat tekan beton BAR-AL lebih rendah $0.85 \mathrm{MPa} \quad(4.2 \%)$ dibandingkan beton BAR-AT sebagai control beton. Hal yang sama juga terjadi pada kuat tekan beton BAR-AT di umur 28 hari sangat terlihat lebih tinggi daripada beton BAR-AL sekitar $6.98 \mathrm{MPa}$ (22.0\%). Sedikit serupa dengan penelitian [12] yang menyimpulkan bahwa material AR menyebabkan penurunan yang signifikan dalam menghasilkan kuat tekan hingga $21 \%$ akibat level penggantian agregat sebesar $75 \%$.

Gambar 5 memperjelas peningkatan kuat tekan beton BAR-AT dan BAR-AL terhadap waktu lamanya perawatan sampel uji. Kuat tekan beton BAR-AT sebagai beton referensi terlihat jelas mengalami peningkatan tajam dari awal 7 hari hingga maksimum di umur 28 hari sebesar $34.2 \%$. Berbeda dengan beton BAR-AL, kekuatan tekan terlihat mengalami peningkatan sedang sebesar $17.9 \%$.

Dari gambaran ini terlihat bahwa tanpa menggunakan air tawar sebagai campuran beton BAR maka kekuatan tekan lebih tinggi dibandingkan dengan beton BAR dengan air laut. Ini kemungkinan sangat dipengaruhi oleh mortar lama dan mortar baru dengan air laut yang tidak memiliki kemampuan menyatu dengan sempurna akibat masih rendahnya kandungan semen. Partikel-partikel beton BAR menjadi lebih tipis dan cenderung mudah retak sehingga ikatan diantarannya menjadi lemah yang berakibat penurunan kekuatan beton [13].

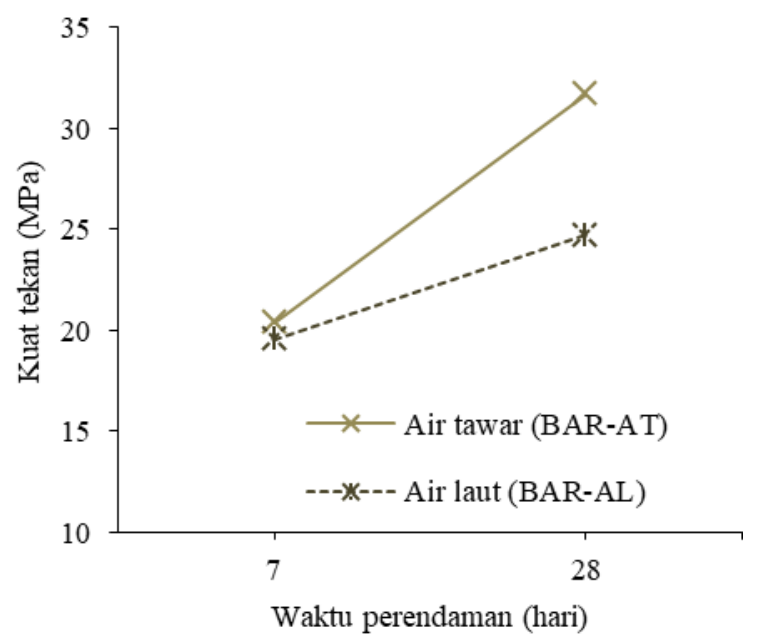

Gambar 5. Kuat tekan vs peningkatan waktu perawatan

\subsection{Hubungan berat sampel, kuat tekan dan umur beton}

Hubungan kuat tekan dan berat rata-rata tiga sampel uji dapat dilihat pada Gambar 6. Secara umum, Kuat tekan lima jenis campuran (B-0, B-50, B-100, BAR-AT, dan BAR-AL) mengalami peningkatan seiring dengan penurunan berat sampel uji silinder beton dari umur 7 hari hingga 28 hari.

Grup pertama, awal umur 7 hari, berat beton B-0, B-50, dan B-100 adalah fluktuatif sebesar 12.8, 12.7, dan $12.9 \mathrm{Kg}$, sedangkan hasil kuat tekan menurun bertahap berturut-turut sebesar 18.9, 17.5, dan 17.3 MPa. Begitu pula terjadi pada akhir pengujian 28 hari, berat beton mengalami penurunan sebesar $0.2,0.1$, dan $0.1 \mathrm{Kg}$, dibandingkan dengan kuat tekan yang terjadi penurunan berturut-turut sebesar 26.8, 25.4, dan $24.9 \mathrm{MPa}$ seiring penggantian jumlah volume material RAK.

Grup kedua, dua jenis campuran (BAR-AT dan BAR-AL), tergambar jelas pengaruh perbedaan kedua berat sampel beton dan kuat tekannya. Awal perawatan 7 hari, 


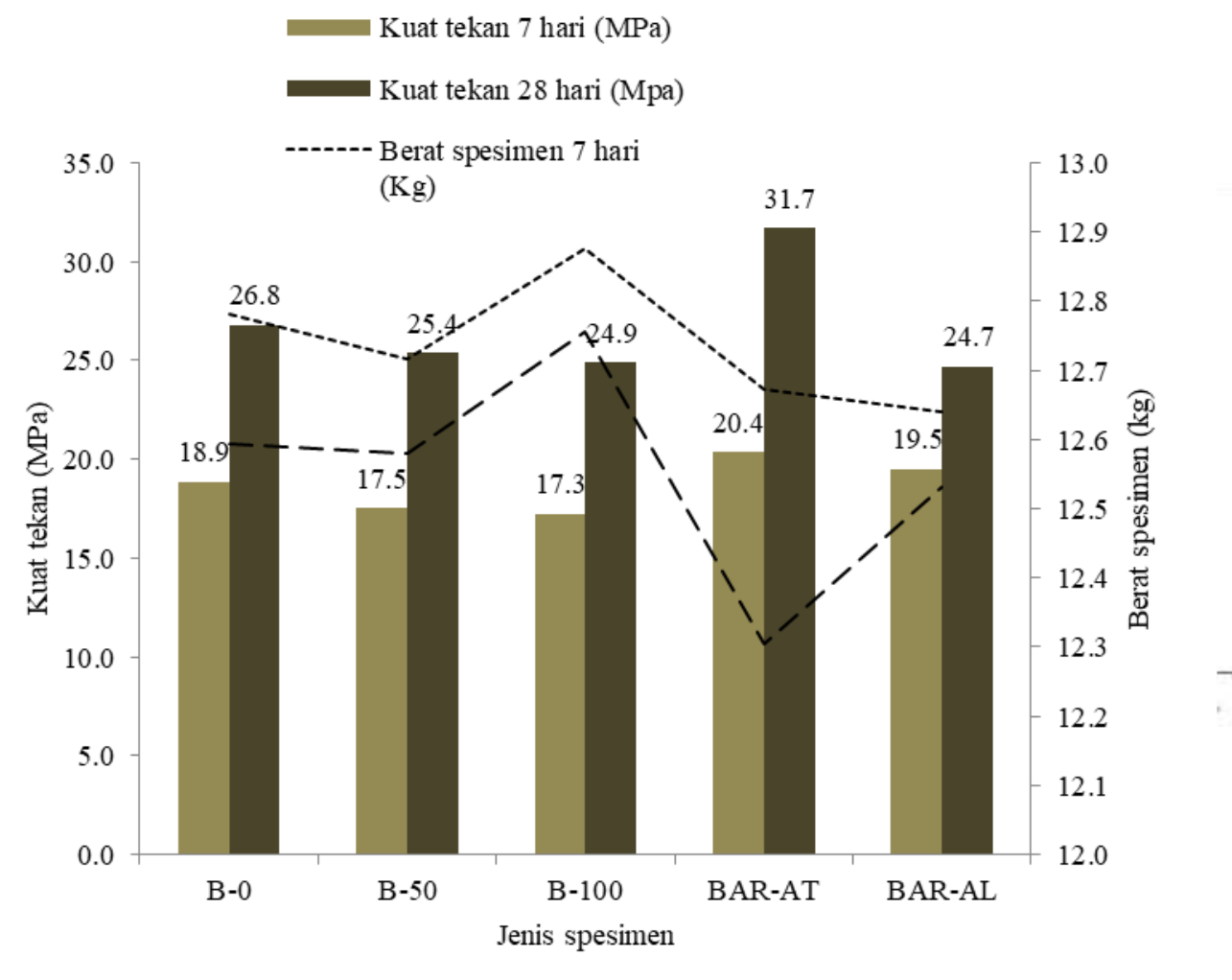

Gambar 6. Kuat tekan vs verat sampel

berat sampel beton adalah sekitar $12.7 \mathrm{Kg}$ untuk BAR-AT dan $12.6 \mathrm{Kg}$ untuk BAR-AL yang setelah pengujian beban tekan diperoleh kuat tekan berturut-turut sebesar 20.5 dan 19.5 MPa. Pada akhir perawatan 28 hari, berat sampel beton mengalami penurunan dan diperoleh nilai berturut-turut sekitar 12.3 dan $12.5 \mathrm{Kg}$, sedangkan hasil kuat tekan berturut-turut sebesar 31.7 dan $24.7 \mathrm{MPa}$.

\subsection{Pola retak silinder beton BAR}
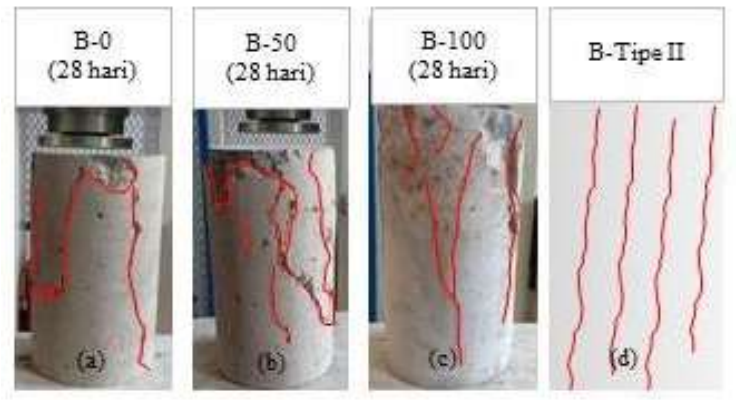

Gambar 7. Pola retak silinder beton (a) B-0,

(b) B-50, (c) B-100, dan B-Tipe II (d)

Sifat keruntuhan beton sangat menetukan kualitas beton yang dihasilkan. Pada umumnya, keruntuhan sampel dapat terjadi satu diantara tiga pola retak seperti pada literatur [14].
Gambar 7 memperlihatkan sifat dan pola keruntuhan benda uji dengan level subtitusi RAK berbeda. Pada pengujian beban tekan 28 hari, seluruh benda uji (a,b dan c) memperlihatkan keruntuhan tipe kedua sebagai referensi (d) dimana hal ini mengindikasikan bahwa kegagalan terjadi ketika kekuatan beton memiliki mutu tinggi dan ekspansi lateral pada ujung permukaan sampel relative tidak terkontrol.

\subsection{Hubungan kuat tekan rencana dan hasil pengujian 28 hari \\ Gambar 8 memperlihatkan korelasi} antara rencana dan realisasi rencana pengujian kuat tekan ke dua grup campuran beton BAR pada umur 28 hari. Dua jenis rencana kuat tekan sebesar $25 \mathrm{MPa}$ dan $30 \mathrm{MPa}$. Hasil pengujian memperlihatkan bahwa seluruh hasil kuat tekan yang diperoleh berada diatas garis beban tekan rencana terendah (25 $\mathrm{MPa})$ dan hampir seluruh berada dibawah garis beban tekan rencana maksimum (30 MPa), kecuali beton BAR-AT yang melampaui garis referensi beban tekan rencana maksimum sebesar 31.7 Mpa. Akan tetapi, tren peningkatan kuat tekan beton dari campuran material RAK dengan air laut akan berada diantara level 25-30 $\mathrm{MPa}$. 
Sehingga beton agregat recycle dengan campuran air laut (BAR-AL) memiliki kemampuan terbatas pada kuat tekan rencana hingga $25 \mathrm{MPa}$.

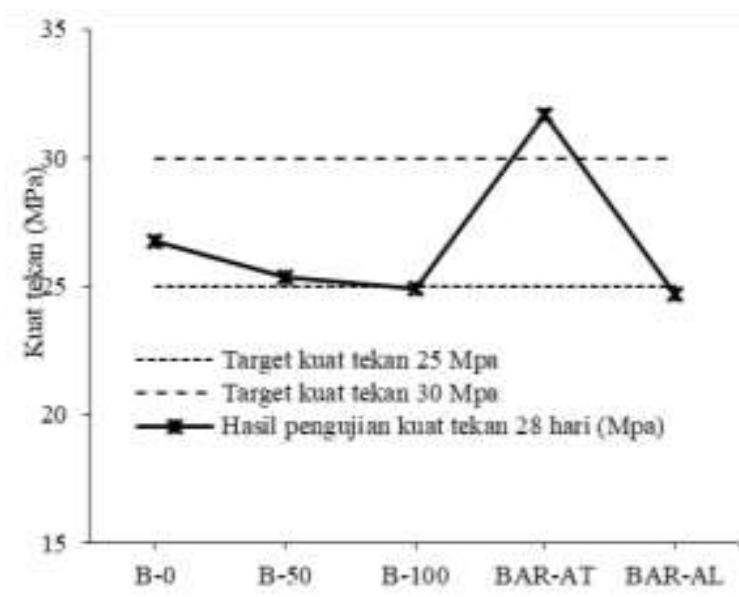

Gambar 8. Realisasi vs rencana kuat tekan umur 28 hari

\section{KESIMPULAN}

Berdasarkan hasil penelitian terbaru tentang efek campuran air laut pada beton recycle agregat dibawah pengaruh beban tekan, berikut ini beberapa kesimpulan yang dapat digambarkan:

1. Penurunan kekuatan tekan beton agregat recycle terjadi baik umur 7 dan 28 hari, seiring bertambahnya persen subtitusi material agregat recycle kasar.

2. Pengaruh mortar lama diyakini memiliki peran penting menurunkan kekuatan tekan beton agregat recycle, akan tetapi air laut sebagai campuran pembuatan beton tidak signifikan berpengaruh terhadap nilai hasil pengujian untuk target kuat tekan sebesar 25 MPa.

3. Beton agregat recycle untuk rencana kuat tekan $30 \mathrm{MPa}$ tanpa campuran air laut tercatat memiliki kuat tekan lebih besar 22\% dibandingkan dengan beton agregat recycle campuran air laut.

4. Seiring waktu dari umur 7 hari hingga 28 hari, Penurunan berat sampel uji akan meningkatkan kuat tekan beton dimana semakin berkurang berat sampel akan meningkatkan kekuatan tekan beton. Hal ini ditandai dengan pola retak pada tipe kedua.

5. Tren peningkatan kuat tekan beton dari campuran material 50-100\% RAK dengan air laut akan maksimal berada pada level hingga $25 \mathrm{MPa}$ dan material 100\% RAK dengan campuran air tawar akan berada pada level lebih besar dari $30 \mathrm{MPa}$.

\section{UCAPAN TERIMA KASIH}

Penelitian ini didukung dan didanai sepenuhnya oleh direktorat penguatan riset dan pengembangan kementrian riset, teknologi, dan perguruan tinggi (kontrak no: 1104/k9/kt03/2018). Atas bantuan dan dukungannya, penulis mengucapkan banyak terima kasih.

\section{DAFTAR PUSTAKA}

[1] K. Mcneil And T. H.-K. Kang, "Recycled Concrete Aggregates: A Review," International Journal Of Concrete Structures And Materials, Vol. 7, No. 1, Pp. 61-69, Mar. 2013.

[2] M. M. El-Hawary And S. F. Al-Otaibib, "On The Durability Of Recycled Aggregates Concrete," Vol. 6, No. 1, P. 4, 2017.

[3] M. Malešev, V. Radonjanin, And G. Bro, "Properties Of Recycled Aggregate Concrete," Contemporary Materials, P. 11, 2014.

[4] T. I. Abdel-Magid, O. M. Osman, O. H. Ibrahim, R. T. Mohammed, S. O. Hassan, And A. A. H. Bakkab, "Influence Of Seawater In Strengths Of Concrete Mix Design When Used In Mixing And Curing," Key Engineering Materials, Vol. 711, Pp. 382-389, Sep. 2016.

[5] R. Alizadeh, P. Ghods, M. Chini, M. Hoseini, M. Ghalibafian, And M. Shekarchi, "Effect Of Curing Conditions On The Service Life Design Of Rc Structures In The Persian Gulf Region," Journal Of Materials In Civil Engineering, Vol. 20, No. 1, Pp. 2-8, Jan. 2008.

[6] M. Islam, S. Islam, And M. Islam, "Suitability Of Sea Water On Curing And Compressive Strength Of Structural Concrete," Journal Of Civil Engineering, P. 9, 2012.

[7] A. Cwirzen, P. Sztermen, And K. Habermehl-Cwirzen, "Effect Of Baltic Seawater And Binder Type On Frost Durability Of Concrete," Journal of Materials In Civil Engineering, Vol. 26, No. 2, Pp. 283-287, Feb. 2014.

[8] F. M. Wegian, "Effect Of Seawater For Mixing And Curing On Structural Concrete," The Ies Journal Part A: Civil \& Structural Engineering, Vol. 3, No. 4, Pp. 235-243, Nov. 2010.

[9] Akshat Dimri, Jay Kr. Varshney, V. K. Verma, Sandeep Gupta, And G.B.Pant University Of Agriculture And Technology, Pantnagar, "A Review On Strength Of Concrete In Seawater," International Journal of Engineering Research And, Vol. V4, No. 03, Mar. 2015. 
[10] F. Lollini, M. Carsana, M. Gastaldi, E. Redaelli, L. Bertolini, And A. Naani, "Preliminary Assessment Of Durability Of Sustainable Rc Structures With Mixed-In Seawater And Stainless Steel Reinforcement," Key Engineering Materials, Vol. 711, Pp. 52-59, Sep. 2016.

[11] M. Kang And L. Weibin, "Effect Of The Aggregate Size On Strength Properties Of Recycled Aggregate Concrete," Advances In Materials Science And Engineering, Vol. 2018, Pp. 1-8, 2018.

[12] T. L. Lau, W. Elleithy, W. K. Choong, T. Y.
Tze, C. M. Lee, And A. L. Modhwadia, "Effects Of Recycled Aggregates On Concrete Strengths," Materials Research Innovations, Vol. 18, No. Sup6, Pp. S6-372-S6-374, Dec. 2014.

[13] G. Yue, P. Zhang, Q. Li, And Q. Li, "Performance Analysis Of A Recycled Concrete Interfacial Transition Zone In A Rapid Carbonization Environment," Advances In Materials Science And Engineering, Vol. 2018, Pp. 1-8, 2018.

[14] M. N. Hassoun, "Structural Concrete," Structural Concrete, Six Edition, Wiley: 2015. 